International Journal of Engineering \& Technology, 7 (2) (2018) 859-867
International Journal of Engineering \& Technology
SPC
Website: www.sciencepubco.com/index.php/IJET
doi: $10.14419 /$ ijet.v7i2.8489
Research paper

\title{
A comparative analysis of the gasification performances of torrefied and untorrefied bagasse: Influence of feed size, gasifier design and operating variables on gasification efficiency
}

\author{
Anthony Anukam ${ }^{1,2 *}$, Omobola Okoh ${ }^{3}$, Sampson Mamphweli ${ }^{4}$, Jonas Berghel ${ }^{1}$ \\ ${ }^{1}$ Environmental and Energy Systems, Department of Engineering and Chemical Sciences, Karlstad University, \\ SE-651 88 Karlstad, Sweden \\ ${ }^{2}$ Fort Hare Institute of Technology, University of Fort Hare, Private Bag X1314, Alice 5700, South Africa \\ ${ }^{3}$ Department of Chemistry, University of Fort Hare, Private Bag X1314, Alice 5700, South Africa \\ ${ }^{4}$ Centre for Renewable and Sustainable Energy Studies, Stellenbosch University, Private Bag X1 Matieland 7602, South Africa \\ *Corresponding author E-mail: anthony.anukam@kau.se
}

\begin{abstract}
This study conducted a comparative assessment of the gasification performances of torrefied and untorrefied bagasse with emphasis on feed size, gasifier design and operating conditions that would influence gasification efficiency. Torrefaction greatly improved the characteristics of bagasse and had significant impact on its gasification performance. The gasifier design parameters studied were throat angle and throat diameter. Temperature of input air and feed input were the gasifier operating conditions examined in the course of the gasification processes of both torrefied and untorrefied bagasse. These parameters were considered the most critical operating parameters that affect gasifier performance and, correlation between the parameters was established in the course of gasification. The results obtained showed higher gasification efficiency for torrefied bagasse in comparison to untorrefied bagasse under varied conditions of gasification, which was attributed mainly to changes in the characteristics of the torrefied material.
\end{abstract}

Keywords: Biomass; Sugarcane Bagasse; Torrefaction; Gasification; Efficiency; Computer Simulation.

\section{Introduction}

Coal is the major solid fuel for energy production in South Africa and, in fact, it's over exploitation has actually exacerbated the concerns about energy related issues that the country is presently faced with. Increasing efforts to partially replace coal with biomass, which is a renewable energy resource, is gradually gaining attention [1]. South Africa has abundant biomass resources that include sugarcane bagasse (SCB), which is generated in large quantities by sugar mills in operation in the country. This biomass residue is a potential feedstock that can be used for energy production through gasification, which will convert the material into solid, liquid or gaseous fuel that can be used to generate electricity and heat through a gas engine [2], [3]. The environmental benefits of the gasification technology cannot be overstated because it involves clean exploitation of a material as conversion of the biomass releases minimal amount of $\mathrm{CO}_{2}$ and other greenhouses gases compared to the conversion of coal.
Gasification relies on partial oxidation at high temperatures to convert biomass into energy [2], [4]. Many different types of gasifiers have been proposed and used for the conversion of biomass to energy, with each type designed according to feedstock characteristics. However, the difference in the types of gasifiers is linked to how the feedstock is introduced into the gasifier [5]. The most commonly used types are the fixed bed, the entrained flow and the fluidized bed gasifiers. The downdraft gasifier (which is a fixed bed type of gasifier) is the focus of this study, so the fundamental chemical kinetics of each gasification technology based on the operation of the downdraft gasifier are described, with emphasis on the four main processes (drying, pyrolysis, oxidation and reduction) occurring in the gasifier. Each of these processes are characterized by its own energy requirements, which can be endothermic or exothermic, with heat and mass transfers as well as the chemical kinetics of the reactions and pore diffusion being the main rate controlling mechanisms involved in the processes. To better understand these rate controlling mechanisms, Figure 1 shows the heat and mass flows characterized by the four main gasification processes. 


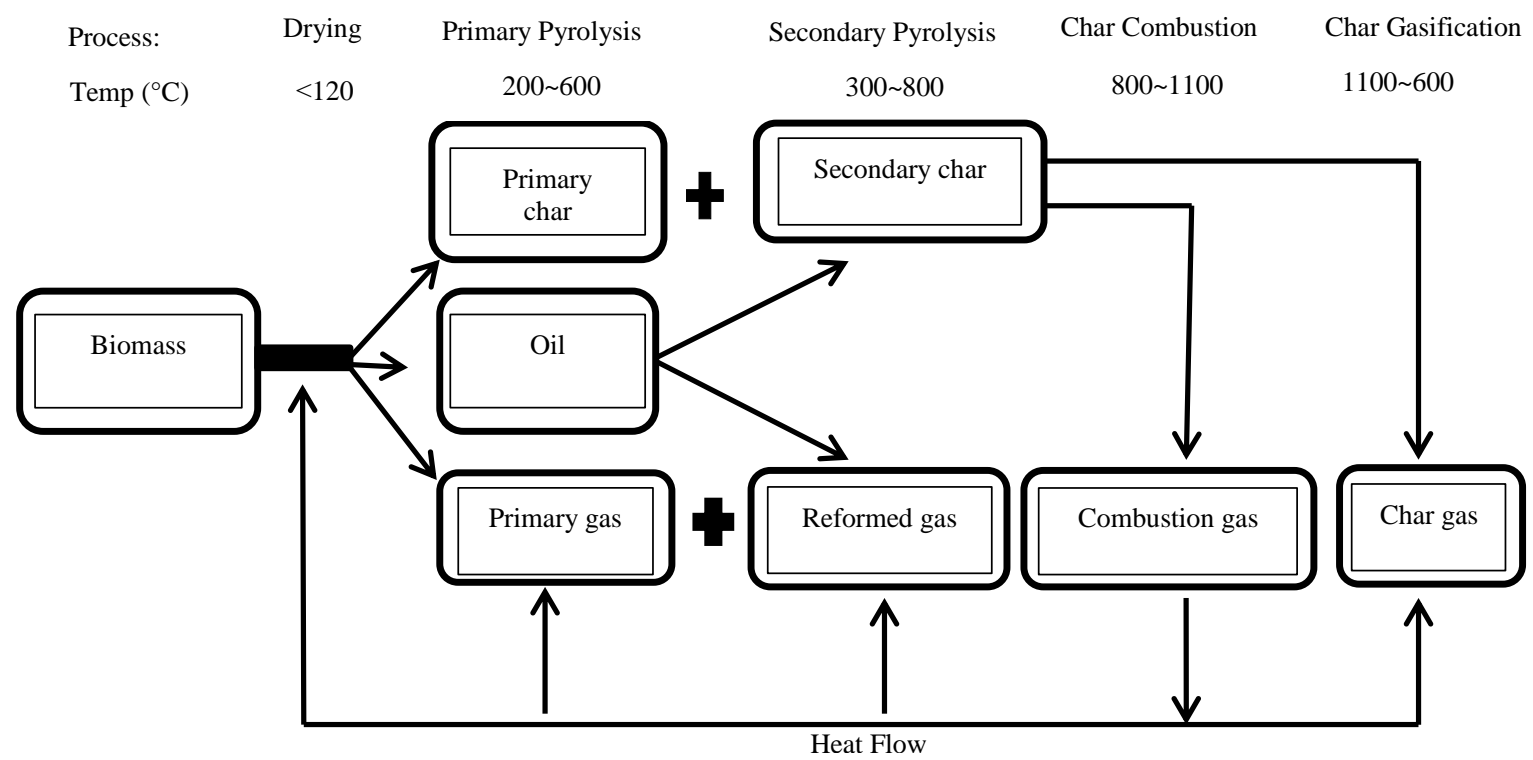

Fig. 1: Heat and Mass Flows in A Gasification Process. Adapted From [6].

The mechanisms of heat and mass flows vary in magnitude according to the physical and chemical processes characterized by each zone; which includes temperature, air moisture, heat losses as well as mass flow rate of air and gas including solid phases, feed rate and feed size together with biomass moisture content [7]. Gasification efficiency, among other factors, is dependent upon fuel characteristics such as feed size, and gasifier design parameters such as throat angle and throat diameter as well as gasifier operating conditions such as temperature and feed input; understanding the impact of these parameters would mitigate challenges involved in the reliable prediction and optimization of the gasification system as well as product composition in order to attain the desired efficiency [8]. However, little information is available on these parameters and their influence on gasification efficiency, thus it was considered necessary to investigate parameters that would impact the efficiency of the gasification process of torrefied sugarcane bagasse under various gasifier design and operating parameters and compare this with the efficiency of the gasification process of untorrefied bagasse obtained from a previous study [4] under the same set of conditions in order to establish the more suitable feedstock (torrefied or untorrefied biomass) for gasification in terms of efficiency.

Studies have actually shown that limited information is available in the literature dealing with the concurrent effects of fuel characteristics such as feed size, gasifier design and operating conditions on gasification efficiency using torrefied biomass as feedstock. Furthermore, information relating to the comparison of the gasification performances of torrefied and untorrefied sugarcane bagasse conducted under the same set of gasification conditions is also lacking in the literature. A study on the gasification of biomass in a fixed bed downdraft gasifier was carried out by Tinaut et al. 2008 [9] who investigated the effects of particle size and air velocity on gasification process efficiency. Pérez et al. 2012 [10] also investigated the impact of gasifier design and operating conditions on the gasification performance of biomass in a downdraft system. Their study considered fuel properties such as particle size and moisture content, and operating conditions such as air velocity. They found that optimal gasification is achieved when biomass particle size and moisture content are not more than $6 \mathrm{~mm}$ and $11 \%$ respectively, and that air velocity must be at least $0.06 \mathrm{~m} / \mathrm{s}$. Similar studies were also conducted by Kramreiter et al. 2008 [11] in a twin-fire fixed bed downdraft gasification system using wood chips as feedstock. They varied parameters such as type of wood chips, power distribution as well as air distribution and established the effect of these parameters not only on syngas composition but also on the content of tar in the syngas and that of carbon in the ash produced in the gasification process. Other studies include those conducted by Thanapal et al. 2012 [12] who studied the influence of equivalence ratio and steam fuel ratio as well as air mixture on the performance of a downdraft gasifier. They concluded that temperature and the production of $\mathrm{CO}_{2}$ as well as that of $\mathrm{O}$ increased at the expense of $\mathrm{CO}$. The study conducted by Yoon et al. 2011 [13] also showed that $\mathrm{H}$ concentration in the syngas produced from the gasification of woody biomass increased with equivalence ratio and steam-to-wood ratio.

Biomass materials differ greatly in composition and characteristics due to a number of reasons, one of which may be attributed to their origin, handling and other conditions; as such, they make different demands as to the type of technology required for their conversion into energy; biomass pre-processing prior to conversion also have obvious influence on its characteristics, which ultimately impacts on downstream process conditions and energy conversion systems design that uses the biomass as feedstock [4]. In this study, a comparative analysis of the characteristics, in terms of feed size, and gasification performances of torrefied and untorrefied bagasse was undertaken with an attempt to establish the influence of feed size, gasifier design and operating variables on gasification efficiency. The results obtained provide good reference point for the design of a laboratory or large scale gasification system that would be suitable for the conversion of sugarcane bagasse.

\section{Materials and methods}

\subsection{Biomass sample}

The biomass material used for this study was sugarcane bagasse obtained from a local sugar mill in South Africa. Bagasse generation in South Africa is about 3 million tons per annum from the 14 sugar mills in the country [14]. This material represents a huge biomass resource with potential as a feedstock for energy production as it is inefficiently combusted by the sugar mills for steam and power production.

Bagasse torrefaction was conducted in a muffle furnace at $250^{\circ} \mathrm{C}$ as a pretreatment method intended to improve characteristics to make it akin to coal properties. Torrefied bagasse was characterized using various analytical instruments and results obtained from these analyses were compared with the characteristics of untorrefied bagasse from a previous study [15]. The influence of the discrepancies in feed characteristics on gasification efficiency was established under various gasifier design and operating conditions. The energy value of torrefied bagasse was measured by a CAL2K model oxygen bomb calorimeter, while its proximate and ultimate analyses were determined by a Perkin Elmer TGA 7 model and a Brucker type elemental analyzer. 


\subsection{Gasification of torrefied bagasse}

The gasification of torrefied bagasse was performed by computer simulation employing a computer programming code developed specifically for the simulation of downdraft gasifiers. The computer code was developed by Chen, 1986 [16] and modified by Jayah, 2002 [7]. The gasification simulation process was conducted under various gasifier design and operating variables to evaluate and establish the influence of these variables on the performance of the gasifier. A detailed description of this simulation tool was presented in a previous study [4].

Gasification simulation was preferred in order to eliminate the time and high costs associated with actual gasification experiments. However, results obtained from this study have been compared with those obtained from a previous study [4] on the gasification performance of untorrefied (raw) bagasse conducted under same analysis conditions.

\subsubsection{Procedure for gasification simulation}

Downdraft gasifiers may be simple in design, but the chemical and technical processes occurring inside them are quite complicated and still not completely understood. There is absolutely no difficulty in having gasification to occur in downdraft systems but to optimally execute the process with high efficiency and high syngas quality remains an issue yet to be addressed because the basic principles underlying its design process are still completely vague, and never described quantitatively hence the many gasifier designs and different approaches to the designs.

The characterization results of torrefied bagasse presented in Table 2 were used during computer simulation of the gasification process. Gas profiles were obtained during simulation and were used to estimate the percentage composition of the combustible gases contained in the syngas. This was followed by determination of the influence of varied gasifier design and operating parameters on gasification efficiency. The parameters varied were throat angle, throat diameter and temperature of input air as well as feed input and feed size. As previously mentioned, these parameters are considered the most critical operating parameters that affect gasifier performance [17]. Table 1 presents the varied parameters and their range of variation.

Table 1: Varied Gasification Parameters and Range of Variation during Computer Simulation

\begin{tabular}{ll}
\hline Parameter & Range \\
\hline Throat angle $\left({ }^{\circ}\right)$ & $25,40,90$ \\
Throat diameter $(\mathrm{cm})$ & $10,30,50$ \\
Temperature of input air $\left({ }^{\circ} \mathrm{C}\right)$ & $25,40,90$ \\
Feed input $(\mathrm{kg} / \mathrm{h})$ & $40,80,100$ \\
Feed size $(\mathrm{cm})$ & $6,20,30$ \\
\hline
\end{tabular}

The efficiency of the gasification process of torrefied bagasse was calculated after computer simulation from eqn. 1 [2]:

$\eta=\left[\left(\frac{E V_{\text {gas }}}{\mathrm{EV}_{\text {fuel }}} \times 2\right) \times 100\right]$

Where $\eta$ is the efficiency of the gasifier, $E V_{\text {gas }}$ is the energy value of the syngas, and $\mathrm{EV}_{\text {fuel }}$ is the energy value of torrefied and untorrefied bagasse as presented in Table 1. The factor ' 2 "' in the equation represents the gas flow rate from the gasifier and is measured in $\mathrm{Nm}^{3} / \mathrm{h}[7]$

\section{Results and discussion}

As earlier mentioned, the findings from this study were compared with those from a previous study [4] on characterization and gasification performance conducted under same analysis conditions in order to establish the more suitable feedstock for gasification in terms of efficiency.

The following sub-sections details the findings from this study, however, it is worthy to note that the proximate and ultimate anal- ysis data presented in Table 2 were calculated on a dry and ashfree basis and that the sum of the weight percentages of the elements represented by ultimate analysis are $97.37 \%$ for torrefied bagasse, and $97.5 \%$ for untorrefied bagasse, meaning that the leftover fractions of $2.63 \%$ and $2.5 \%$ were considered fractions of other elements not investigated in this study. The elements presented are considered the major elemental components of bagasse relevant to its energy conversion [4].

\subsection{Comparison of the quintessential characteristics of torrefied and untorrefied bagasse}

There have been a number of studies performed on biomass characteristics for different applications, however, the wide variability of biomass characteristics and how these affect energy conversion systems is not completely understood and requires further investigation to understand the quintessential properties of biomass and how they influence energy conversion systems; operating a gasification system and controlling the processes occuring within the system requires knowledge of the basic properties of the biomass used as feedstock as understanding the fundamental characteristics of the biomass is key to successful operation of the gasifier [4]. Table 2 shows a comparison of the characteristics of torrefied bagasse obtained from this study, and the characteristics of untorrefied bagasse from a previous study.

Table 2: Measured Key Characteristics of Torrefied Bagasse Compared with Those of Its Parent Material from A Previous Study

\begin{tabular}{lll}
\hline \multicolumn{3}{l}{ with Those of Its Parent Material from A Previous Study } \\
\hline & $\begin{array}{l}\text { Torrefied } \\
\text { Bagasse }\end{array}$ & Untorrefied Bagasse [15] \\
\hline $\begin{array}{l}\text { Proximate analysis } \\
\text { (wt. \%) }\end{array}$ & \\
Moisture content & 0.87 & 1.08 \\
Volatile matter content & 54.07 & 73.73 \\
Fixed carbon & 28.45 & 23.87 \\
Ash & 16.61 & 1.32 \\
Ultimate analysis (wt. \%) & & \\
C & 56.16 & 44.1 \\
H & 3.94 & 5.7 \\
O & 37.27 & 47.7 \\
N & 1.80 & 0.20 \\
O-C molar ratio & 0.66 & 2.08 \\
H-C molar ratio & 0.07 & 0.13 \\
Other properties & & \\
Energy value (MJ/kg) & 20.19 & 17.86 \\
\hline
\end{tabular}

The standard analyses errors for the proximate and ultimate analyses of torrefied and untorrefied sugarcane bagasse were between 0.5 and $1 \%$, while their energy value was $<0.4 \mathrm{MJ} / \mathrm{kg}$. However, Table 2 reveals quite a significant difference in the characteristics of torrefied and untorrefied bagasse. The low moisture content recorded was as a result of the removal of waterforming groups such as the hydroxyl groups $(-\mathrm{OH})$ from torrefied bagasse, which creates a hydrophobic fuel property that favours gasification [18], [19]. Increased amount of volatiles were evaporated during torrefaction due to decomposition of primary bagasse components, creating a condition that contributed to the reduction in the volatile matter content of torrefied bagasse and raising its energy value to $20 \mathrm{MJ} / \mathrm{kg}$. This was basically attributed to the reduction in $\mathrm{O}-\mathrm{C}$ ratio of torrefied bagasse. During gasification, biomass particles are decoposed into volatile gases such as $\mathrm{CO}, \mathrm{H}_{2}, \mathrm{CO}_{2}, \mathrm{CH}_{4}$, charcoal and tar, which are pyrolysis zone products that flow downward to the combustion zone of the gasifier where they are fiercely burnt with homogenous distribution of air to release huge quantities of heat needed to meet the demand of the whole gasification process. High combustion zone temperature facilitates reduction reactions as well as tar cracking for improved gas calorific value [20, 21]. Due to the release of enormous amount of volatiles that created its depletion during torrefaction of bagasse, residual ash was accumulated hence the increased ash composition $(16.61 \%)$ recorded for torrefied bagasse. This increased weight percentage of ash in torrefied bagasse may create technical hitches linked to 
agglomeration, fouling and sintering that constributes to low gasification efficiency [22]. In contrast to volatile matter content, the weight percentage of fixed carbon, which is affected by the other three properties (moisture content, volatile matter content and ash), increased after torrefaction. The weight percentages of volatile matter and fixed carbon are linked to the relative yields of solid, liquid and gaseous products formed during gasification [23]. Elemental analysis show that $\mathrm{C}$ composition was significantly raised after torrefaction, which is in agreement with most findings in the literature including those reported by Kleinschmidt, 2011 [24 - 29]. However, the higher the weight percentage of $C$ in biomass the higher would be the energy value of the biomass and the higher would also be the temperature of gasification [8], [27]. The weight percentage of $\mathrm{O}$ in torrefied bagasse also reduced significantly. The content of $\mathrm{O}$ in raw biomass is usually consumed when the biomass is subjected to thermal pretreatment such as torrefaction because of the reactions occuring as the biomass releases both condensable and non-condensable compounds, which was the main reason for the low $\mathrm{O}-\mathrm{C}$ ratio recorded for torrefied bagasse [30], [31]. H composition was also slightly reduced, an indication that syngas $\mathrm{H}$ composition may be slightly lowered. However, the amount of moisture made available through fuel $\mathrm{H}$ content determines the extent of the formation of the water-gas shift reaction that forms the major part of the syngas [4].

The difference in energy value between torried and untorrefied bagasse is also glaring in Table 2. This was attributed to increase in the carbon content of torrefied bagasse and the reduction in its oxygen content. Among other factors, gasification efficiency is based upon feedstock energy value [15].

\subsection{Influence of feed size, gasifier design and operating variables on gasifier efficiency}

Gasifier performance, syngas quality and the heat and mass flow reactions presented in Figure 1 are all affected by fuel characteristics, design and operating variables of the gasification system [7], [32 - 34]. Torrefied bagasse showed improved properties after torrefaction in comparison to untorrefied bagasse, which was established after characterization using various analytical instruments relevant to gasification.

The following sub-sections presents the influence of various parameters on gasification efficiency during gasification of torrefied bagasse from this study and gasification of untorrefied bagasse from a previous study [4].

\subsubsection{Influence of feed size on gasification efficiency}

Gasification feedstock size (FS) is a significant characteristic in any gasification process and system design with important influence on the burning properties of the biomass because it affects heating and drying rates during gasification $[35,36]$. The influence of varied feed size on gasification efficiency for torrefied bagasse is presented in Figure 2a. This was obtained after computer simulation using the parameters presented in Table 2 , with only feed size varied at the expense of other parameters. Results obtained were compared with those from the gasification of untorrefied bagasse from a previous study (Figure 2b) [4].
(A)

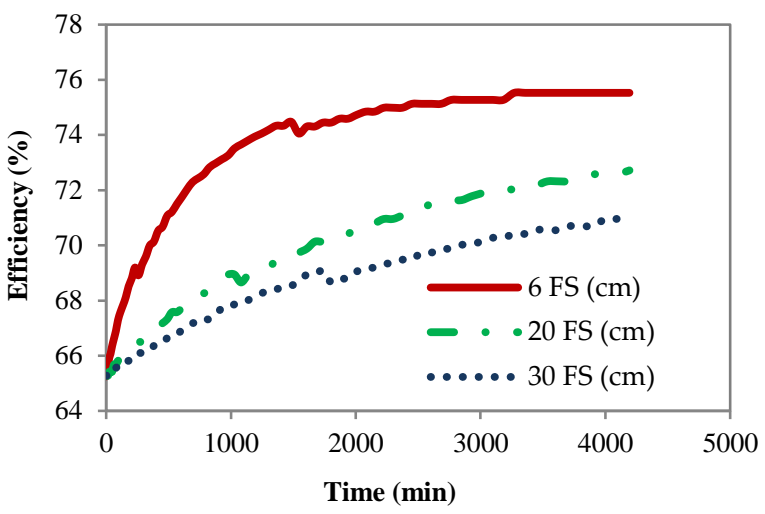

(B)

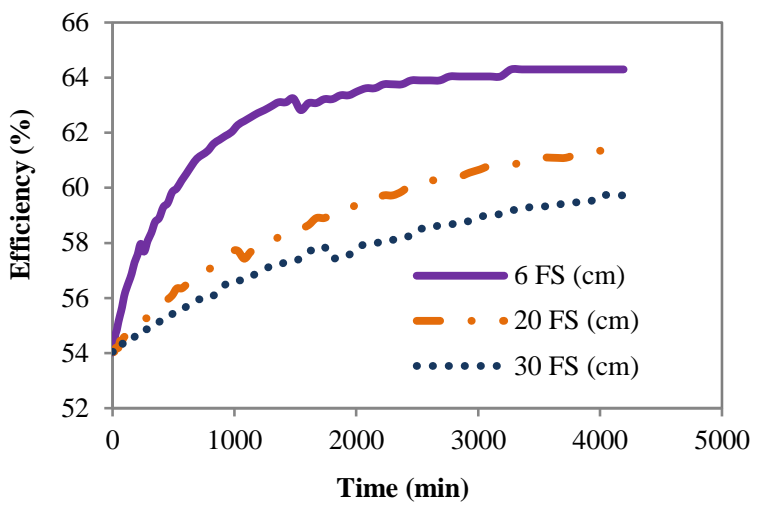

Fig. 2: Influence of Varied Feed Size on the Efficiency of Gasification: (A) Torrefied Bagasse Gasification from This Study; (B) Untorrefied Bagasse Gasification from A Previous Study [4].

It can be seen from Figure 2 ( $a$ and $b$ ) that the plots are similar in shape, a reason attributed to gasification simulation of same material. However, the major observable differences in the plots are reflected in the efficiency achieved during gasification of both materials under the same gasification simulation conditions. Although, both plots show that gasification efficiency increases with reducing feed size, which is because reduced feed sizes have larger surface areas per unit mass as well as larger pore sizes that facilitates faster rates of heat transfer and gasification [37]. The gasification efficiency achieved with torrefied bagasse is over $10 \%$ higher than that achieved using its counterpart (untorrefied bagasse) as feedstock under same conditions of varied feed size. This difference in gasification efficiency was a consequence of the dissimilarity in the chemical properties and calorific value of torrrfied and untorrefied bagasse. Torrefaction instigates decomposition of the most reactive biomass components such as hemicellulose and depolymerization reactions that lead to improved biomass properties for the purpose of gasification [38], [39]. Another reason to the dissimilarity in properties between torrefied and untorrefied bagasse was also linked to the slight degradation of lignin during torrefaction, which led to inter-penetration of amorphous polymer molecules between components of torrefied bagasse. This was believed to have played a role in the gasification efficiency achieved with torrefied bagasse. Lignin decomposition and its subsequent flow during torrefaction of biomass results in inter-penetration of amorphous polymer molecules between adjacent biomass particles would have positive impact when torrefied biomass is used as feedstock in energy conversion systems [40, 41]. Because of modifications in the composition of biomass as a result of torrefaction and with the help of a gasifying agent, a high and uniform gasification temperature is achieved in the oxidation and reduction zones of the gasifier for better tar cracking and higher gas yield, which are a reflection of optimum gasification efficiency [42]. This implies that biomass pretreatment aimed at reducing feed size is consequential to successful operation of a 
gasification system as supported by Anukam et al. 2016 [27] and Xue et al. 2014 [33].

\subsubsection{Influence of feed input on gasification efficiency}

Increasing biomass feed input during gasification is quite beneficial for improved production capacity; however, when feed input is excessively increased it will lead to higher gas yield, which may result in low gas quality as a consequence of increased tar yield and other impurities [43]. The influence of feed input (FI) on gasification efficiency for the gasification process of torrefied bagasse is presented in Figure 3a. Again, for the purpose of comparison, the gasification efficiency for untorrefied bagasse obtained from a previous study under same analysis conditions is presented in Figure 3b.

(A)

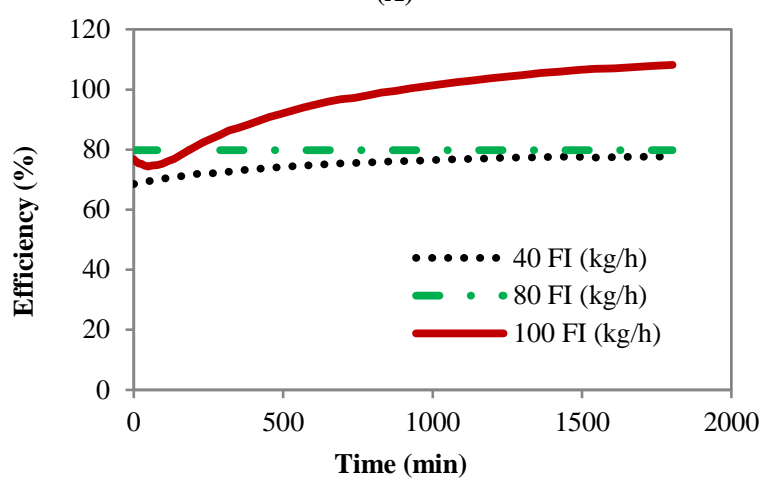

(B)

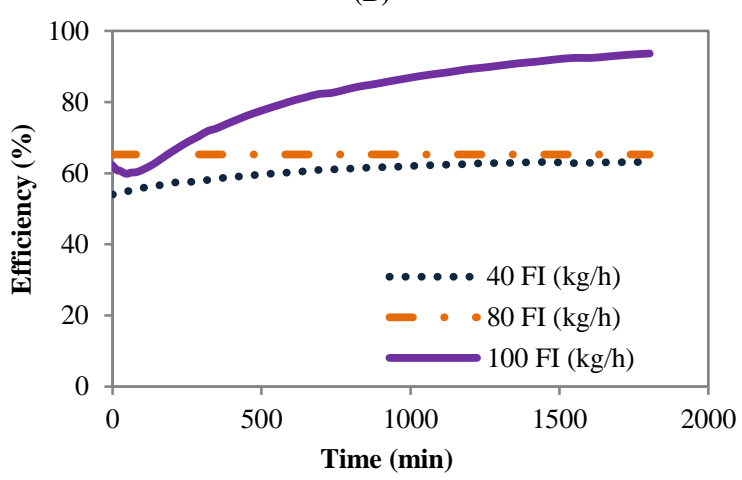

Fig. 3: Influence of Varied Feed Input on Gasification Efficiency: (A) Torrefied Bagasse Gasification from This Study; (B) Untorrefied Bagasse Gasification from A Previous Study [4]

Apparently, from Figure 3 (a and b), gasification efficiency also increased with increasing feed input, which was attributed to increased temperatures during gasification simulation. A high value of biomass feed input will speed up the rate of reactions within the gasifier, especially with regard to the strong oxidation reactions, leading to increased gasification efficiency as a consequence of rise in temperature caused by the oxidation reactions [42]. However, the efficiencies obtained during gasification of torrefied bagasse were much higher than those attained using its counterpart (untorrefied form) under the same varied conditions of feed input, which is in good agreement with the findings of Xue et al. 2014 [33]. This is true because the gasification simulation process of torrefied bagasse showed better temperature increase that was perpetuated by increased rate of chemical reactions as the feed input increased, compared to the temperature rise in the gasification simulation process of untorrefied bagasse. This was attributed to the improved properties of torrefied bagasse since the amorphous and crystalline regions of the material were broken through torrefaction, making torrefied bagasse more amenable to gasification than untorrefied bagasse. Breaking the amorphous and crystalline regions of biomass through torrefaction reflects improved properties of the biomass that makes the biomass amenable to thermochemical conversion such as gasification; untorrefied biomass remains thermally unstable when used as feedstock in gasification processes because of increased amount of oxygen that leads to formation of condensable tar, which create issues that may be linked to gas-line blockages [44 - 46]. The increased temperature and rate of reactions resulted in improved $\mathrm{CO}$ and $\mathrm{H}$ production that led to complete conversion of torrefied bagasse and decreased char yield. This generally implies that feed input is key to successful operation of a gasification system.

\subsubsection{Influence of temperature of input air on gasification efficiency}

During biomass gasification, temperature of input air is usually supplied in order to aid combustion and provide energy needed for gasification as well as to initiate partial oxidation of the elements contained in the feedstock; syngas composition and yield depends on the operating temperature of the gasifier because the reactions taking place in the gasifier are temperature dependent and, downdraft gasifiers are generally operated at ambient air temperatures of about $27^{\circ} \mathrm{C}$ [7], [47]. Figure 4a shows the influence of varied temperature of input air on gasification efficiency of the gasification process of torrefied bagasse, which was compared with the efficiency obtained for gasification of untorrefied bagasse from a previous investigation under same conditions of varied temperature of input air (Figure $4 b$ ).

(A)

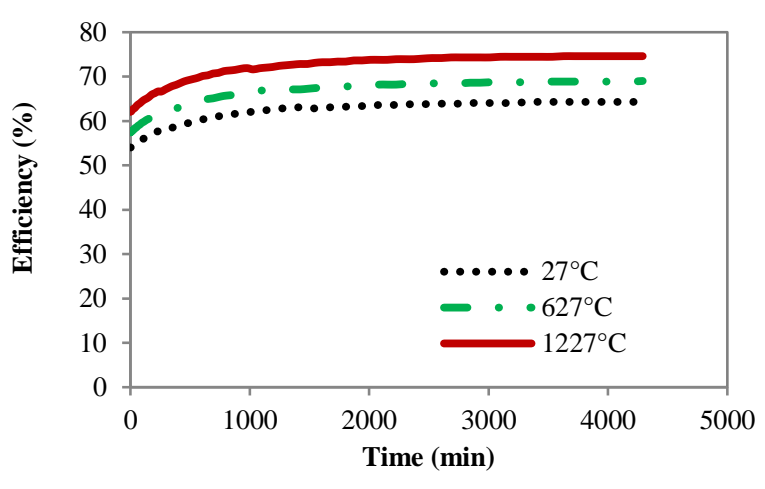

(B)

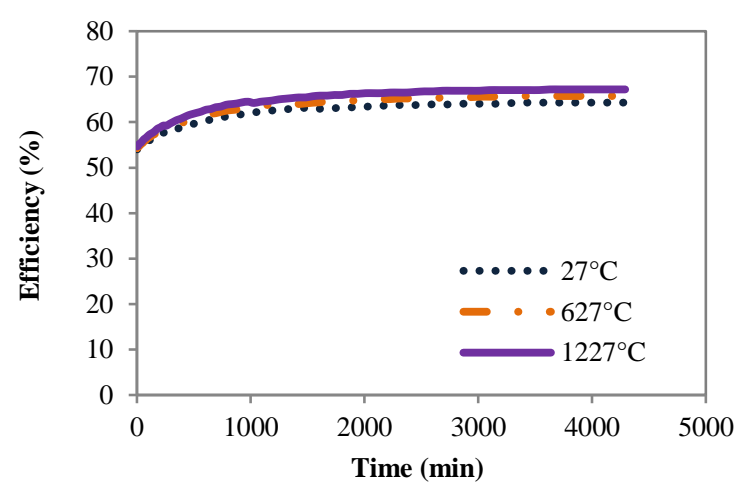

Fig. 4: Influence of Varied Temperature of Input Air on the Efficiency of Gasification: (A) Torrefied Bagasse Gasification from this Study; (B) Untorrefied Bagasse Gasification from A Previous Study [4]

Increasing temperature of input air favoured gasification as efficiency increased with increasing temperature of input air because of additional enthalpy provided by hot air for the gasification reactions, as depicted in Figures 4 (a and b). The efficiency of the gasification process of torrefied bagasse increased from $64 \%$ to $69 \%$ when temperature of input air was raised from $27^{\circ} \mathrm{C}$ to $627^{\circ} \mathrm{C}$, reaching a maximum of ca. $75 \%$ efficiency when it was raised to $1227^{\circ} \mathrm{C}$. On the contrary, gasification efficiency for un- 
torrefied bagasse obtained from a previous investigation and presented in Figure $4 \mathrm{~b}$ reached a maximum of $67 \%$ under same varied temperature of input air. This observation was attributed to difference in material characteristics, especially with regard to hydrophobic properties because some $-\mathrm{OH}$ groups in the molecular structure of torrefied bagasse were reduced due to torrefaction, leading to an increase in hydrophobic properties that made torrefied bagasse more susceptible to igniting faster than anticipated. The hydrophobic properties of torrefied bagasse allowed heat to easily spread over the entire gasifier area by convection during gasification simulation, a condition which agrees with the findings of Wilk et al. 2015 [18] and Venselaar, 1982 [32]. High temperature of input air is conducive to the production of a gas rich in $\mathrm{CO}$ and $\mathrm{H}$ with increased heating value, a condition which reflects high gasification efficiency during biomass gasification [43], [48].

\subsubsection{Influence of throat angle on gasification efficiency}

The throat in downdraft gasifiers are remarkable distinctive features of the system with huge influence on gasification efficiency because of the significance attached to its main function, which is to evenly distribute heat around the oxidation zone of the gasifier and consequently down the reduction zone as this heat distribution is important for optimum efficiency [8, 30, 49]. Figure 5a shows the influence of varied throat angle on the efficiency of the gasification process of torrefied bagasse. This was also compared with a previous study on the gasification of untorrefied bagasse presented in Figure $5 \mathrm{~b}$ under same varied design conditions of throat angle.

(A)

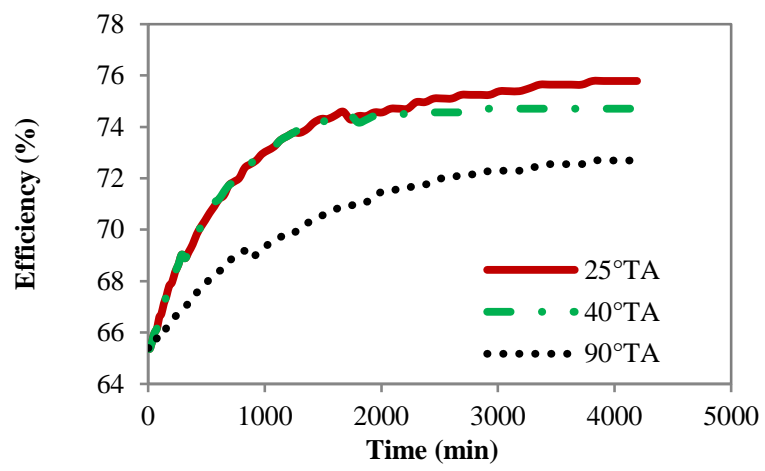

(B)

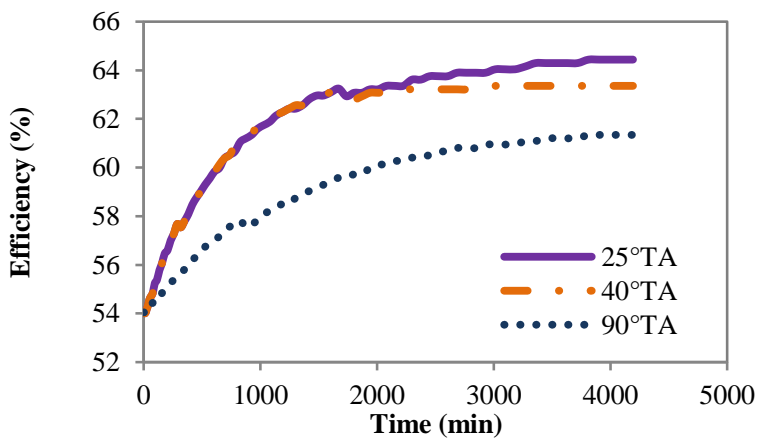

Fig. 5: Influence of Varied Throat Angle on Efficiency of Gasification: (A) Torrefied Bagasse Gasification from this Study; (B) Untorrefied Bagasse Gasification from A Previous Study [4].

According to Figure 5 ( $a$ and $b$ ), gasification efficiency decreases as throat angle increases, a condition that was attributed to the effect of divergence as a result of decreasing reaction temperature and reaction rate. Contrary to the maximum efficiency of $64 \%$ achieved with untorrefied bagasse (Figure $5 \mathrm{~b}$ ) under the same design conditions of varied throat angle (TA), optimum gasification efficiency of ca. $75 \%$ was achieved with the smallest throat angle (TA) of $25^{\circ}$ (evident in Figure 5a). This constitutes a difference of about $11 \%$, which is significant enough to allude that tor- refied bagasse is a better feedstock for gasification than untorrefied bagasse as reported by Anukam et al. 2016 [27] and Xue et al. 2014 [33], especially when smaller feed sizes are used along with reduced throat angles. The gasification efficiencies achieved were due to a combination of factors which includes the use of smaller gasifier throat angle, the properties of the torrefied material (which were improved upon torrefaction prior to gasification), the conditions under which gasification was undertaken, etc. Improved biomass properties will enhance biomass conversion efficiency in thermochemical conversion processes such as in gasification processes, especially employing systems with constricted throat angles [30], [32], [50], [51]. These properties impacted on the performance of torrefied bagasse during gasification, especially with respect to alteration in the physical and chemical properties of torrefied bagasse. These also constituted the main reasons for the high energy value reported for torrefied bagasse in Table 2 . Reduced $\mathrm{O}-\mathrm{C}$ ratio of biomass will raise the energy value of biomass and will consequently result in improved gasification characteristics of the biomass in terms of efficiency [26], [52].

\subsubsection{Influence of throat diameter on gasification efficiency}

The throat diameter was another design parameter considered in this study. The main factor determining the right circumstances for gasification to take place lies in the cross-sectional area of the gasifier, in this case, the throat dimensions of the gasifier [32]. The throat of a downdraft gasifier is situated just around the oxidation zone of the gasifier. Its main functions had been described in a previous section. However, Figure 6a shows the influence of varied throat diameter on gasification efficiency for torrefied bagasse, while Figure $6 \mathrm{~b}$ depicts the efficiency obtained from a previous study on the gasification of untorrefied bagasse under same conditions of varied throat diameter.

(A)

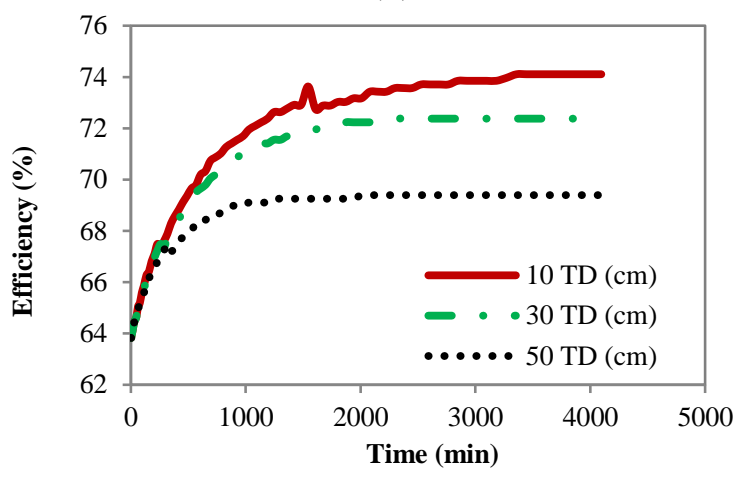

(B)

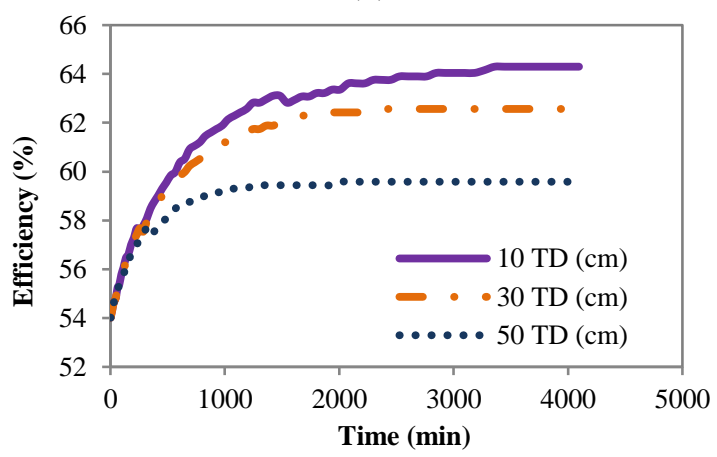

Fig. 6: Influence of Varied Throat Diameter on Gasification Efficiency: (A) Torrefied Bagasse Gasification from this Study; (B) Untorrefied Bagasse Gasification from A Previous Study [4].

From Figure 6 ( $\mathrm{a}$ and $\mathrm{b}$ ), it can be noted that optimum gasification efficiency was achieved with the smallest throat diameter $(10 \mathrm{~cm})$, a reason attributed to the fact that larger throat diameters (30 and $50 \mathrm{~cm}$ ) decrease reaction temperature and reaction rate as a result 
of divergence related effects. Cold spots can occur when the throat diameter of the gasifier is too large, leading to reduced gasification efficiency [32]. The maximum efficiency achieved with the smallest throat diameter during gasification of torrefied bagasse according to Figure $6 \mathrm{a}$ is about $74 \%$ compared to around $64 \%$ efficiency achieved with untorrefied bagasse from a previous investigation under same reduced throat diameter of $10 \mathrm{~cm}$. The reason for this efficiency was attributed to the design of the simulated throat diameter of the downdraft system, which played a role in preventing bridging and channeling of the feed. The type of throat used during gasification simulation was a two-sided air inlet imbert type of throat that creates great sensitivity to feed size and density. The imbert type of throat in downdraft gasifiers create great sensitivity to biomass particle size as well as density; the throat design is limited to feedstocks with not just uniform size but also with small particle sizes [53]. Optimum gasification efficiency for torrefied bagasse was achieved with relative ease under varied throat diameter because of easy ignition as a result of its flaky and hydrophobic characteristics orchestrated by torrefaction. This created rapid gasification reaction rates that positively influenced gasification efficiency.

\subsection{Concluding discussion}

Inconsistency in biomass quality makes it difficult to use as feedstock in energy conversion systems including gasification systems hence the need to subject the biomass to some kind of pretreatment measures as a way to improve its quality to make it amenable for energy conversion [51]. Therefore, sugarcane bagasse was torrefied to convert it into a feed with a lot more favourable properties. Results showed great discrepancies not just in the characteristics of torrefied and untorrefied bagasse but also disparity in their gasification performances under same conditions of gasification. The elemental components presented in Table 2 are the main constituting blocks of the three major components of biomass (cellulose, hemicellulose and lignin) [54]. The first step in the syngas production process during gasification simulation was the activation of these compounds. After activation, parallel reactions were further initiated by the precursor compounds in the pyrolysis stage through fragmentation reactions and carbon bond scission, which indicated thermal cracking of tar and the formation of free radicals. The fragmentation reactions were favoured at high heating rates and high gasification temperatures.

For torrefied bagasse, a feed size of $6 \mathrm{~cm}$ resulted in ca. $76 \%$ gasification efficiency as compared to the $64 \%$ achieved using untorrefied bagasse as gasification feedstock with same feed size. This was attributed to changes linked to inter-penetration of amorphous polymer molecules between bagasse particles because of the slight degradation of lignin during torrefaction. Maximum mixing of gases occurred at high temperature regions of the gasifier and with reduced feed size, which further increased gasification efficiency due to constricted gasifier throat, an indication of a correlation between feed size, gasifier design and operating variables. Syngas composition and tar decomposition also reflected increased gasification efficiency for torrefied bagasse. These conditions were influenced by feed size, gasifier design parameters and operating conditions, and further indicated a correlation between these parameters.

Although, exact temperature is dependent upon biomass characteristics such as feed size and the gasification system employed as well as the conditions of gasification, the process of biomass gasification is a complex process that involves interactions of both physical and chemical properties of the biomass at temperatures higher than $600^{\circ} \mathrm{C}[4,55]$. As such, there is considerably lack of information on the gasification behavior of torrefied biomass under different gasification conditions and therefore, better knowledge on this topic is required.

\section{Conclusions}

Common events that occurred during torrefaction of bagasse included drying, carbonization, devolatilization, depolymerization and recondensation. These events created material color change that indicated improved properties and exposed the brittle nature of torrefied bagasse, providing a baseline for the presentation of the results of this study. Remarkable differences in the characteristics of torrefied and untorrefied bagasse were observed as the former showed improved properties in comparison to the latter.

Gasification simulation established that torrefied bagasse can create increased temperature in the oxidation and reduction zones of the gasifier, which allowed for the cracking of higher molecular weight compounds that condensed into tar. Greater enhancement of oxidation zone reactions was experienced during the gasification simulation process of torrefied bagasse, which liberated a lot of heat that caused a rise in temperature. This condition also created turbulent gas mixing that led to optimum efficiency due to feed size and gasifier design parameters, among other factors. This was not the case for the conditions experienced during the gasification simulation process of untorrefied bagasse conducted in a previous study [4]. The oxidation zone reactions were slowly initiated and caused increasing tar yield during gasification simulation of untorrefied bagasse, whereas facilitation of the oxidation zone reactions caused rapid and increasing tar cracking and contributed to reduction in the yield of tar that culminated into higher gasification efficiency during gasification simulation of torrefied bagasse. The efficiency attained during gasification of torrefied bagasse was around $10 \%$ higher than that achieved for the gasification of untorrefied bagasse under same conditions of gasification simulation. This difference in efficiency is significant enough to allude that torrefied bagasse is a better feedstock for gasification than untorrefied bagasse because of improved properties instigated by torrefaction. This statement was corroborated by other researchers who agreed that because of changes in characteristics resulting from torrefaction of biomass, the value of torrefied biomass as a fuel is significantly higher than that of untorrefied biomass [27], [25], [28].

\section{Acknowledgments}

This research was supported by the Environmental and Energy Systems research group of the Department of Engineering and Chemical Sciences, Karlstad University, the National Research Foundation of South Africa and the Govan Mbeki Research and Development Centre of the University of Fort Hare including the Department of Chemistry and the Fort Hare Institute of Technology, University of Fort Hare. Their supports are gratefully acknowledged.

\section{References}

[1] D.Y.C. Leung, X.L. Yin, C.Z. Wu, 'A review on the development and commercialization of biomass gasification technologies in China'. Renew. Sustain. Energy Rev. 2004, 8, 565-580. https://doi.org/10.1016/i.rser.2003.12.010.

[2] N.S. Mamphweli, L.E. Meyer, 'Evaluation of the conversion efficiency of a $180 \mathrm{Nm}^{3} / \mathrm{h}$ Johannson biomass gasifier', Int. J. Energy Environ. 2010, 1, 113-120.

[3] P. Wang, S.H. Zhan, H.B. Yu, X.F. Xue, N. Hong, 'the effects of temperature and catalysts on the pyrolysis of industrial wastes (herb residue)'. Bioresour. Technol. 2010, 101, 3236-3241. https://doi.org/10.1016/j.biortech.2009.12.082.

[4] A. Anukam, S. Mamphweli, E. Meyer, O. Okoh, 'Computer simulation of the mass and energy balance during gasification of sugarcane bagasse'. J. Energy 2014, 1-15. https://doi.org/10.1155/2014/713054.

[5] M.M. Pickett, 'Modeling the performance and emissions of British gas/lurgi-based integrated gasification combined cycle systems", Master's Thesis, North Carolina State University, North Carolina, USA, 2000. 
[6] T.B. Reed, "Types of gasifiers and gasifier design considerations", Biomass gasification, Principles and Technology, ed T. B. Reed, Noyes Data Corp., New Jersey, 1981, 184-199.

[7] T.H. Jayah, 'Evaluation of a downdraft wood gasifier for tea manufacturing in Sri Lanka', Master's Thesis, The University of Melbourne, Melbourne, Australia, 2002.

[8] S. Kumar, K. Pitchandi, E. Natarajan, 'Modeling and simulation of downdraft wood gasifier', J. Appl. Sci. 2008, 8(2), 271-279. https://doi.org/10.3923/jas.2008.271.279.

[9] F. Tinaut, A. Melgar, J.F. Pérez, A. Horrillo, 'Effect of biomass particle size and air superficial velocity on the gasification process in a downdraft fixed bed gasifier: an experimental and modelling study". Fuel Process. Technol. 2008, 89, 1076-1089. https://doi.org/10.1016/j.fuproc.2008.04.010.

[10] J.F. Pérez, A. Melgar, P.N. Benjumea, ''Effect of operating design and parameters on the gasification/combustion process of waste biomass in fixed bed downdraft reactors: an experimental study", Fuel 2012, 96, 478-496. https://doi.org/10.1016/j.fuel.2012.01.064.

[11] R. Kramreiter, M. Url, J. Kotik, H. Hofbauer, 'Experimental investigation of a $125 \mathrm{~kW}$ twin-fire fixed bed gasification pilot plant and comparison to the results of a $2 \mathrm{MW}$ combined heat and power plant (CHP)',. Fuel Process. Technol. 2008, 89, 90-102. https://doi.org/10.1016/j.fuproc.2007.08.001.

[12] S.S. Thanapal, K. Annamalai, J.M. Sweeten, G. Gordillo, 'Fixed bed gasification of dairy biomass with enriched air mixture', Appl. Energy 2012, 97, 525-531. https://doi.org/10.1016/j.apenergy.2011.11.072

[13] H.C. Yoon, T. Cooper, A. Steinfeld, 'Non-catalytic autothermal gasification of woody biomass', Int. J. Hydrogen Energy 2011, 36, 7852-7860. https://doi.org/10.1016/j.ijhydene.2011.01.138.

[14] T.J. Hugo, 'Pyrolysis of sugarcane bagasse'. Master's Thesis, University of Stellenbosch, Stellenbosch, South Africa, 2010.

[15] A. Anukam, S. Mamphweli, E. Meyer, O. Okoh, 'Gasification of sugarcane bagasse as an efficient conversion technology for the purpose of electricity generation'. A Multidisciplinary Journal the University of Fort Hare 2013, 20(1), ISSN: 0015-8054, 58-75.

[16] J. Chen, 'Kinetic engineering modeling of co-current moving bed gasification reactors for carbonaceous material". Ph.D. Thesis, Cornell University, New York, NY, USA, 1986.

[17] T.B. Reed, A. Das, 'Handbook of biomass downdraft gasifier engine system,' SERI, Golden, Colorado, 1988 https://doi.org/10.2172/5206099.

[18] M. Wilk, A. Magdziarz, I. Kalemba, 'Characterisation of renewable fuels' torrefaction process with different instrumental techniques". Energy 2015, 87, 259-269. https://doi.org/10.1016/j.energy.2015.04.073.

[19] P. Tanger, J.L. Field, C.E. Jahn, M.W. de Foort, J.E. Leach, ' Biomass for thermochemical conversion: Targets and challenges". Rev. Artic. Front. Plant Sci. 2013, 218(4): 218-230. https://doi.org/10.3389/fpls.2013.00218.

[20] L. Devi, K.J. Ptasinski, F. Janssen, "A review of the primary measures for tar elimination in biomass gasification processes". Biomass Bioenergy 2003, 24, 125-140. https://doi.org/10.1016/S0961-9534(02)00102-2.

[21] S.C. Bhattacharya, S.S. Hla, H.L. Pham, 'A A study on a multi-stage hybrid gasifier engine system'. Biomass Bioenergy 2001, 21, 445460. https://doi.org/10.1016/S0961-9534(01)00048-4.

[22] A. Toptas, Y. Yildirim, G. Duman et al. 'Combustion behaviour of different kinds of biomass and their blends with lignite', Bioresour. Technol. 2015, 177, 328-336. https://doi.org/10.1016/j.biortech.2014.11.072.

[23] J.S. Brar, K. Singh, J. Wang, S. Kumar, 'Co-gasification of coal and biomass: A review'. Int. J. For. Res. 2012, 1-10. https://doi.org/10.1155/2012/363058.

[24] C.P. Kleinschmidt, 'Overview of international developments in torrefaction'. Proceedings of the IEA Bioenergy Task 32 and Task 40 Workshop, 28 January 2011, Graz, Austria, International Energy Agency,

Paris. (http://www.ieabcc.nl/worshops/task32_2011_graz_torrefaction/Kl einschmidt_Paper.pdf)

[25] T.C. Acharjee, C.J. Coronella, V.R. Vasquez, 'Effect of thermal pretreatment on equilibrium moisture content of lignocellulosic biomass"'. Bioresour. Technol. 2011, 102(7), 4849-4854. https://doi.org/10.1016/j.biortech.2011.01.018.

[26] M.J. Prins, K.J. Ptasinski, F. Janssen, 'More efficient biomass gasification via torrefaction'. Energy 2006c, 31(15), 3458-3470. https://doi.org/10.1016/j.energy.2006.03.008.

[27] A.I. Anukam, S.N. Mamphweli, P. Reddy, O.O. Okoh, 'Characterization and the effect of lignocellulosic biomass value addition on gasification efficiency'. Energ. Explor. Exploit. 2016, 34(6) 865 880. https://doi.org/10.1177/0144598716665010.

[28] N. Brosse, R. El Hage, M. Chaouch, M. Petrissans, S. Dumarcay, P. Gerardin, 'Investigation of the chemical modifications of beech wood lignin during heat treatment', Polym. Degrad. Stab. 2010, 95(9),

1721-1726. https://doi.org/10.1016/j.polymdegradstab.2010.05.018

[29] J. Kiel, F. Verhoeff, H. Gerhauser, B. Meuleman, ''BO2technology for biomass upgrading into solid fuel-pilot-scale testing and market implementation',. Presented at the 16th European Biomass Conference \& Exhibition, Valencia, Spain, 2-6 June 2008 , Energy Centre of the Netherlands, Petten. (http://www.ecn.nl/docs/library/report/2008/m08036.pdf).

[30] Q. Chen, J.S. Zhou, B.J. Liu, Q.F. Mei, Z.Y. Luo, 'Influence of torrefaction pretreatment on biomass gasification technology". Chin. Sci. Bull. 2011, 56(14), 1449-1456. https://doi.org/10.1007/s11434-010-4292-z.

[31] C. Couhert, S. Salvador, J.M. Commandre, 'Impact of torrefaction on syngas production from wood'. Fuel 2009, 88, 2286-2290. https://doi.org/10.1016/i.fuel.2009.05.003.

[32] J. Venselaar, 'Design rules for downdraft wood gasifiers: A short review,' Joint Technical Assistance Project, JTA-9A-Research Development1 at the Institut Teknologi Bandung, Indonesia, 1982 $1-24$.

[33] G. Xue, M. Kwapinska, W. Kwapinski, K.M. Czajka, J. Kennedy, J.J. Leahy, 'Impact of torrefaction on properties of miscanthus giganteus relevant to gasification',. Fuel 2014, 121, 189-197. https://doi.org/10.1016/j.fuel.2013.12.022.

[34] B. Moghtaderi, 'Effects of controlling parameters on production of hydrogen by catalytic steam gasification of biomass at low temperatures". Fuel 2007, 86(15), 2422-2430. https://doi.org/10.1016/j.fuel.2007.02.012.

[35] P. Basu, V. Mettanant, L. Augustus, 'Gasification of rice husk in supercritical water'. Mechanical Engineering Department, Dalhousie University 1360, Barrington St., Halifax, NS B3J 1Z1, Canada, 2010.

[36] D. Ciolkosz, 'Characteristics of biomass as a heating fuel'. Renewable and Alternative Energy Fact Sheet. Penn State College of Agricultural Sciences. Agricultural Research and Coorporative Extension. www.energy.extension.psu.edu (2010). Last accessed November 2012.

[37] V. Kirubakaran, V. Sivaramakrishnan, R. Nalini, T. Sekar, M. Premalatha, P. Subramanian, "A review on gasification of biomass"'. Renew. Sustain. Energy Rev. 2009, 13, 179-186. https://doi.org/10.1016/j.rser.2007.07.001

[38] D. Medic, M. Darr, A. Shah, B. Potter, J. Zimmerrnan, ''Effects of torrefaction process parameters on biomass feedstock upgrading', Fuel 2011, 91(1), 147-154 https://doi.org/10.1016/i.fuel.2011.07.019.

[39] A. Shah, M.J. Darr, D. Medic, R.P. Anex, D. Maski, S. Khanal, 'Techno-economic analysis of a production-scale torrefaction system for cellulosic biomass upgrading', Biofuels, Bioprod. Biorefin. 2012, 6(1), 45-57. https://doi.org/10.1002/bbb.336.

[40] W. Stelte, J.K. Holm, A.R. Sanadi, S. Barsberg, J. Ahrenfeldt, U.B. Henriksen, "A study of bonding and failure mechanisms in fuel pellets from different biomass resources". Biomass Bioenergy 2011d $35(2)$, https://doi.org/10.1016/j.biombioe.2010.11.003

[41] W. Stelte, C. Clemons, J.K. Holm, R.A. Sanadi, L. Shang, J. Ahrenfeldt, U.B. Henriksen, 'Fuel pellets from wheat straw: The effect of lignin glass transition and surface waxes on pelletizing properties'. Bioenerg. Res. 2012a, 5(2), 450-458. https://doi.org/10.1007/s12155-011-9169-8.

[42] F. Guo, Y. Dong, L. Dong, C. Guo, ''Effect of design and operating parameters on the gasification process of biomass in a downdraft fixed bed: An experimental study'. Int. J. Hydrogen Energy 2014 39, 5625-5633. https://doi.org/10.1016/j.ijhydene.2014.01.130.

[43] Y.J. Lu, L.J. Guo, C.M. Ji, X.M. Zhang, X.H. Hao, Q.H. Yan, "Hydrogen production by biomass gasification in supercritical water-A parametric study'. Int. J. Hydrogen Energy 2006, 31, 822 831. https://doi.org/10.1016/j.ijhydene.2005.08.011.

[44] B.M. Jenkins, L.L. Baxter, T.R. Miles (Jr), T.R. Miles, 'Combustion properties of biomass'. Fuel Process. Technol. 1998, 54, 1746. https://doi.org/10.1016/S0378-3820(97)00059-3.

[45] J.S. Tumuluru, R.D. Boardman, C.T. Wright, J.R. Hess, "'some chemical compositional changes in miscanthus and white oak sawdust samples during torrefaction', Energies 2012, 5(10), 39283947. https://doi.org/10.3390/en5103928.

[46] P.A. Jensen, B. Sander, K. Dan-Johasen, 'Pretreatment of straw for power production by pyrolysis and char wash". Biomass Bioen- 
ergy 2001, 20, 431-446. https://doi.org/10.1016/S09619534(01)00005-8.

[47] V. Dillibabu, E. Natarajan, 'Effect of temperature and equivalence ratio on gasification of biomass"'. J. Chem. Pharm. Sci. 2014, 4, 92-94.

[48] C. Lucas, D. Szewczyk, W. Blasiak, S. Mochida, 'Hightemperature air and steam gasification of densifies biofuels',. Biomass Bioenergy 2004, 27, 563-575. https://doi.org/10.1016/j.biombioe.2003.08.015.

[49] S. Mamphweli, 'Physics 505 lecture notes'. University of Fort Hare. Unpublished lecture notes, 2009.

[50] T.G. Bridgeman, J.M. Jones, A. Williams, D.J. Waldron, ''an investigation of the grindability of two torrefied energy crops"'. Fuel 2010, 89(12), 3911-3918. https://doi.org/10.1016/j.fuel.2010.06.043.

[51] M.J.C. van der Stelt, H. Gerhauser, J.H.A. Kiel, K.J. Ptasinski, 'Biomass upgrading by torrefaction for the production of biofuels: a review". Biomass Bioenergy 2011, 35(9), 3748-3762. https://doi.org/10.1016/j.biombioe.2011.06.023.

[52] D.R. Nhuchhen, P. Basu, B. Acharya, 'A comprehensive review on biomass torrefaction', Int. J. Renew. Energy Biofuels 2014, 1, 156.

[53] S. Chopra, A.K. Jain, 'A review of fixed bed gasification systems for biomass". Agricultural Engineering International 2007: the CIGR Ejournal. Invited Overview No. 5. Vol. IX.

[54] K. Kanniappan, 'Production of biomass by gasification using coconut shell'. Int. J. Sci. Res. 2015, 4(5), 1-6.

[55] U. Arena, 'Process and technological aspects of municipal solid waste gasification. A review'. Waste Managmt. 2012, 32(4), 625639. https://doi.org/10.1016/j.wasman.2011.09.025. 